\title{
Sub-Chronic Toxicity Evaluation of Tannery Waste Water to Clarias gariepinus Juveniles
}

\author{
*11IBRAHIM, SS; ${ }^{1}$ IMAM, TS; ${ }^{2}$ ZUNGUM, IU \\ ${ }^{* 1}$ Department of Biological Sciences, Bayero University Kano, P.M.B. 1515, Kano State, Nigeria \\ ${ }^{2}$ Department of Biological Sciences, Federal University Gashua, P.M.B. 1005, Yobe State, Nigeria \\ *Corresponding Author Email: Shamcyah.is@gmail.com
}

\begin{abstract}
This paper was conducted to investigate the sub-chronic toxicity of tannery effluents sourced from Challawa industrial estate Kano, Nigeria using Clarias gariepinus. The study covered physicochemical parameters, haematological, and biochemical stress enzymes assessments. The water quality results revealed mean value of Temperature $\left(29.92 \pm 1.93^{\circ} \mathrm{C}\right), \mathrm{pH}(8.14 \pm 0.85)$, DO $(1.60 \pm 0.38 \mathrm{mg} / \mathrm{l})$, BOD $(0.77 \pm 0.16 \mathrm{mg} / \mathrm{l})$, Salinity $(7.75 \pm 0.60 \mathrm{mg} / \mathrm{l})$, Nitrate $(1.19 \pm 0.05 \mathrm{mg} / \mathrm{l})$ and Phosphate $(16.48 \pm 0.85 \mathrm{mg} / \mathrm{l})$. After termination of 21 days sub-chronic test, haematological and biochemical changes analysed were generally considered significantly different $(\mathrm{P}<0.05)$ within the treatments. The haematological indices revealed a decrease and sudden increase in concentration of estimated values of PCV, $\mathrm{Hb}, \mathrm{RBC}$, $\mathrm{MCHC}$ and $\mathrm{MCH}$, while WBC and MCV fluctuated. These may be attributed to stress, the duration of exposure and levels of pollutants in the effluent. Furthermore, oxidative stress enzymes followed an order of SOD > CAT > GSH. This could be due to level of pollutants in the effluent. The results of the data indicated tannery effluent to have a toxic effect on the experimented organism. The information calls for a more enrich toxicity testing that should involve wide range of organisms. It should entail reproductive aspects of the species, detail relationship and enhanced methodological procedures.
\end{abstract}

\section{DOI:https://dx.doi.org/10.4314/jasem.v25i8.22}

Copyright: Copyright $(\odot 2021$ Ibrahim et al. This is an open access article distributed under the Creative Commons Attribution License (CCL), which permits unrestricted use, distribution, and reproduction in any medium, provided the original work is properly cited.

Dates: Received: 10 May 2021; Revised: 28 June 2021; Accepted: 01 July 2021

Keywords: Clarias gariepinus, sub chronic toxicity, tannery effluent, physiochemical, haematological indices

Being among the most polluting industrial sectors, tannery effluent in Nigeria is directly or indirectly discharged into rivers resulting in toxic effects on aquatic life as well as polluting the environment (Chowdhury et al., 2015: Likita et al., 2016). Many typical processes are used in treating and assessing level of toxicity in tannery wastewater such as biological process, oxidation process and chemical process. Among these conventional methods, physical and chemical methods are considered the most widely use but expensive and energy consuming (Jahan et al., 2014). However, the contaminated wastewater, soil and vegetables physicochemical parameters vary with place and time. The analysis has certain restriction despite giving basic information of contamination, therefore, toxicity test is peculiarly important in research and producing proper indicators of industrial effluent to toxicity control (Xiao et al., 2016). Principally, tannery effluent has hazardous pollutants having dark brown colour, odour, high content of toxic and varying level of persistent organic substances (Jahan et al., 2014; Tadessa and Guya, 2017). Developed countries have environmental agencies with defined policy to monitors and handle wastewater discharges detecting problem before outbreak of epidemics. Contrarily, the reverse is the case in developing countries like Nigeria where environmental problems are growing at faster rate due to lack of enforcement of laws (Zungum et al., 2020; Wakawa et al., 2008). Observation proclaims a wide variety of reproductive and developmental problems in wildlife and humans caused by exposure to environmental contaminants that can interfere with endocrine signalling pathways (Liney et al., 2005). Therefore, pollutants in discharge effluent can be quickly absorbed or ingested via food chain (Zungum et al., 2019; Abalaka 2015; Parveen et.al., 2017) affecting the health status of aquatic organisms. Fishes are widely used to evaluate the health and physiological risk of aquatic ecosystem serving as biomarkers of environmental pollution (Ogundiran et al., 2010). Here, exposing them to the effluents has displayed histopathological degradations, haematological changes and environmental oxidative stress in response to toxicants. Since investigations carried out on tannery effluent in Kano were largely on physicochemical parameters, with little information on toxicity to biota. As reported by Akan et al. (2009), Ezike et al. (2012), Bernand and Ogunleye (2015), and Umar et al. (2017) among many 
other researchers on characterization of tannery effluent in Kano State, it was revealed that most of the parameters in the effluents have exceeded the maximum allowable limits by WHO, FEPA, USEPA, and NESREA for discharge into the environment. Hence the present study was designed to assess the sub-chronic toxicity of tannery effluent through haematological parameters and antioxidative stress enzymes using a common fish (C. gariepinus). Thus, serves as ideal tools for toxicity studies of the released tannery effluent.

\section{MATERIALS AND METHOD}

Study Sites and Effluent Collection:The effluent was collected from a tannery industry in Challawa industrial estates Kumbotso local government area of Kano state.Grab samples of effluent produced by the industry was collected using 50L jerry cans washed with water and then rinsed with the effluent.

Using standard analytical methods (APHA, 2005), a portion of effluent was used for in-situ measurement of physicochemical parameters; Temperature, $\mathrm{pH}$, DO, $\mathrm{BOD}_{5}$ (measured after 5 days and calculated as $\mathrm{DO}_{1}-\mathrm{DO}_{5}$ ) and salinity using Hanna Waterproof pH/TDS/EC/ Temperature Meters (HI 991300) and combined water quality meter model 8603.

Test Organisms:Clarias gariepinusn Juveniles of size $7.5-8.5 \mathrm{~cm}$ and weight $2.9-3.6 \mathrm{~g}$ were employed as purchased from Rumbun Kifi Dorayi, Kano state. The fishes were acclimatized by renewal bioassay using borehole water for fourteen days in Biological Science Departmental Aquarium prior to toxicity test and fed with commercial feed of $1 \mathrm{~mm}$ size. Feeding was stopped for 24 hours prior to and during exposure period that lasted for 96 hours. The experiment was set up in a completely randomized design manner (Tijani and Ajani, 2017).

Sub-Chronic Toxicity Assay:After a preliminary testing, ten acclimatized fishes were subjected to varying concentrations of $12.5 \%, 6.25 \%, 3.16 \%$, and $1.56 \%$ of tannery effluent in replicates using static renewal bioassay (ASTM, 1990). The fishes are fed after the effluent at the set concentrations were replenished every 24 hours for 21 days.

Haematological Studies:The method employed for collection of blood was in accordance to Dahunsi and Oranusi (2013) where blood was sampled from three C. gariepinus survivors of each treatment at the end of experiment. By severe caudal puncture, blood was collected using $1 \mathrm{ml}$ insulin syringe to estimate numbers of erythrocytes (RBC) and leukocytes (WBC), haemoglobin ( $\mathrm{Hb}$ ) and Haematocrit (Hct) using appropriate described method from Tijjani and Ajani (2017). From the results of $\mathrm{R}$ b B8C count, WBC count, $\mathrm{Hb}$ and $\mathrm{PCV}$, the mean corpuscular volume (MVC), mean corpuscular haemoglobin $(\mathrm{MVH})$ and the mean corpuscular haemoglobin concentration (MCHC) were calculated using the formulas (Dacie and Lewis, 1984):

$$
\begin{gathered}
\operatorname{MCHC}(\mathrm{g} / \mathrm{dl})=\frac{\mathrm{Hb}(\mathrm{g} / \mathrm{dl}) \times 100}{\mathrm{Pcv}(\%)} \\
\mathrm{MCH}(\mathrm{pg} / \text { cell })=\frac{\mathrm{Hb}(\mathrm{G} / \mathrm{dl}) \times 10}{\mathrm{RBC} \text { count in million } \mathrm{mm}-6} \\
\operatorname{MCV}(\mathrm{fl} / \text { cell })=\frac{\mathrm{PCV}(\%) \times 10}{\mathrm{RBC} \text { count in million } \mathrm{mm}-6}
\end{gathered}
$$

Biochemical Analysis:Antioxidative stress enzymes were determined from the supernatant fraction of the liver homogenates of sacrificed $C$. gariepinus with normal saline. Catalase Activity (CAT) was measured using Abebi's method (1974), Reduced glutathione (GSH) was done according to Ellman (1959) as described by Rajagopalan et al. (2004) and Superoxide dismutase (SOD) was determined by the method describe by Fridovich (1989).

Statistical Analysis:Data obtained from haematological and biochemical analyses were analysed using SPSS 16.0 software. Duncan Multiple Range tests (DMRT) as post-hoc test was done after confirmation using one-way ANOVA at 0.05 level of significance.

\section{RESULTS AND DISCUSSION}

The physicochemical results of untreated tannery effluent compared to international and national standard limit are shown in Table 1 . Temperature and $\mathrm{pH}$ mean value were $29.92 \pm 1.93^{\circ} \mathrm{C}$ and $8.14 \pm 0.85$ respectively, revealing that they were within the standard permissible limit. The nitrate, $\mathrm{DO}$, and $\mathrm{BOD}_{5}$ mean values recorded were below standards while phosphates do not conform to NESREA (2009) and WHO (2012) standards.

Results of haematological parameters were presented in Table 2 with mean values significantly different ( $>0.05)$ among and across treatment levels. The mean values of blood parameters as $\mathrm{Hb}, \mathrm{PCV}, \mathrm{RBC}, \mathrm{MCV}$ generally decreased with increase in concentration while WBC fluctuate and a slight fluctuation in MCV was observed. The values of RBC had an increase at $3.16 \%$ concentration but continued to decline with increase in concentration. 
Table 1: Mean Physicochemical Characteristics of the Crude Tannery Effluent as Compared toStandards

\begin{tabular}{|c|c|c|c|}
\hline Parameters & Effluent Discharge & WHO Standard (2012) & NESREA Standard (2009) \\
\hline Temperature $\left({ }^{\circ} \mathrm{C}\right)$ & $29.94 \pm 1.93$ & $30-36$ & - \\
\hline pH & $8.13 \pm 0.85$ & $6.5-8.5$ & $6.5-8.5$ \\
\hline DO (mg/l) & $1.60 \pm 0.39$ & 10 & 6 \\
\hline BOD $_{5}(\mathrm{mg} / \mathrm{l})$ & $0.77 \pm 0.16$ & $20-40$ & - \\
\hline Salinity (mg/l) & $7.75 \pm 0.60$ & - & - \\
\hline $\mathrm{NO}_{3}^{-}(\mathrm{mg} / \mathrm{l})$ & $1.19 \pm 0.05$ & - & 10 \\
\hline $\mathrm{PO}_{4}^{-3}(\mathrm{mg} / \mathrm{l})$ & $16.48 \pm 0.85$ & - & 3.5 \\
\hline References & This work & Onyidoh (2017) & Adeogun and Chukwuka (2012) \\
\hline
\end{tabular}

When compared with the control, MCHC had a decline at the least concentration $(1.56 \%)$ with another sharp elevation at the highest concentration (12.5\%). Even though MCV decreased as concentration increases, there was increase in mean value at $6.25 \%$.
The pattern of blood parameters implied a concentration dependent relationship with the control recording the highest values at almost all blood parameters except for $\mathrm{WBC}, \mathrm{MCHC}$ and $\mathrm{MCH}$.

Table 2: Haematological Characteristics of C. gariepinus Exposed to Varying Concentrations of the Tannery Effluents After Chronic Assay

Concentration Estimate Count of Blood

\begin{tabular}{|c|c|c|c|c|c|c|c|}
\hline of effluent (\%) & PCV (\%) & $\mathrm{Hb}(\mathrm{g} / \mathrm{dl})$ & WBC $\left.\left(10^{3}\right) \mu \mathrm{l}\right)$ & RBC $\left(10^{6}\right) \mu l$ & MCHC (g/dl) & MCV(fl/cell) & MCH (pg/cell) \\
\hline 12.5 & $12.33 \pm 1.16^{\mathrm{a}}$ & $7.80 \pm 0.46^{\mathrm{a}}$ & $9352.67 \pm 220.73^{b}$ & $1.67 \pm 0.16^{\mathrm{a}}$ & $63.40 \pm 2.81^{\mathrm{c}}$ & $73.89 \pm 3.11^{\mathrm{a}}$ & $46.81 \pm 1.65^{\mathrm{c}}$ \\
\hline 6.25 & $22.00 \pm 1.00^{\mathrm{b}}$ & $8.60 \pm 0.10^{\mathrm{ab}}$ & $8006.67 \pm 640.81^{\mathrm{a}}$ & $2.71 \pm 0.07^{b}$ & $39.13 \pm 1.33^{b}$ & $80.93 \pm 11.06^{\mathrm{a}}$ & $31.74 \pm 0.49^{\mathrm{a}}$ \\
\hline 3.16 & $25.33 \pm 3.51^{\mathrm{b}}$ & $9.53 \pm 0.93^{\mathrm{bc}}$ & $10598.67 \pm 237.20^{\mathrm{cd}}$ & $3.13 \pm 0.01^{\mathrm{c}}$ & $37.80 \pm 2.30^{\mathrm{ab}}$ & $77.30 \pm 6.14^{\mathrm{a}}$ & $30.46 \pm 2.89^{\mathrm{a}}$ \\
\hline $\begin{array}{l}1.56 \\
0.00\end{array}$ & $\begin{array}{l}29.00 \pm 1.73^{c} \\
\mathbf{3 0 . 3 3} \pm \mathbf{1 . 1 6}^{\mathbf{c}}\end{array}$ & $\begin{array}{l}10.13 \pm 0.95^{\mathrm{c}} \\
\mathbf{1 2 . 1 3} \pm \mathbf{0 . 5 9 ^ { \mathrm { d } }}\end{array}$ & $\begin{array}{l}11016.67 \pm 10.41^{\mathrm{d}} \\
\mathbf{1 0 0 8 5 . 6 7 \pm \mathbf { 1 3 8 . 0 5 }} \mathbf{5}^{\mathbf{c}}\end{array}$ & $\begin{array}{l}3.01 \pm 0.03^{\mathrm{c}} \\
\mathbf{3 . 1 3} \pm \mathbf{0 . 0 4 ^ { \mathrm { c } }}\end{array}$ & $\begin{array}{l}34.90 \pm 1.28^{a} \\
\mathbf{4 0 . 0 1}^{\mathrm{a}} \mathbf{1 . 4 8}\end{array}$ & $\begin{array}{l}96.32 \pm 4.91^{\mathrm{b}} \\
\mathbf{9 7 . 0 0} \pm \mathbf{2 . 7 7 ^ { b }}\end{array}$ & $\begin{array}{l}33.65 \pm 2.88^{\mathrm{a}} \\
\mathbf{3 8 . 8 0} \pm \mathbf{1 . 4 8}\end{array}$ \\
\hline
\end{tabular}

Mean of 3 replicates \pm SD

Values with the same superscript along the same column are not significantly different $(\mathrm{p}>0.05)$

Table 3 gives result of antioxidative stress enzymes (CAT, GSH and SOD) in comparison with the control showing increase and decline in values. The mean values found to be significantly different $(p>0.05)$, highest value of CAT $(20.76 \pm 0.41 \mu / \mathrm{mg}$ protein $)$ and GSH $(54.13 \pm 0.35 \mu / \mathrm{ml})$ was recorded at $12.5 \%$. The least mean value of $14.83 \pm 0.90 \mu / \mathrm{mg}$ protein was recorded for CAT at $1.56 \%$ and $45.77 \pm 0.25 \mu / \mathrm{ml}$ at $6.25 \%$ for GSH. In case of SOD, the highest value was recorded at $6.25 \%(15.00 \pm 0.30 \mu / \mathrm{ml})$ and the lowest was at $12.5 \%(12.07 \pm 1.86 \mu / \mathrm{ml})$.

Table 3: Antioxidative Stress Enzymes of $C$. gariepinus Liver Exposed to Varying Concentrations of the Tannery Effluents After Chronic Assay

\begin{tabular}{llll}
\hline $\begin{array}{l}\text { Concentration } \\
\text { of effluent }(\%)\end{array}$ & $\begin{array}{l}\text { CAT }(\boldsymbol{\mu} / \mathbf{m g} \\
\text { protein) }\end{array}$ & GSH $(\boldsymbol{\mu} / \mathbf{m l})$ & SOD $(\boldsymbol{\mu} / \mathbf{m l})$ \\
\hline $\mathbf{1 2 . 5}$ & $20.76 \pm 0.41^{\mathrm{c}}$ & $54.13 \pm 0.35^{\mathrm{d}}$ & $12.07 \pm 1.86^{\mathrm{a}}$ \\
$\mathbf{6 . 2 5}$ & $16.33 \pm 0.25^{\mathrm{b}}$ & $45.77 \pm 0.25^{\mathrm{a}}$ & $15.00 \pm 0.30^{\mathrm{b}}$ \\
$\mathbf{3 . 1 6}$ & $15.37 \pm 0.42^{\mathrm{a}}$ & $46.17 \pm 0.35^{\mathrm{a}}$ & $14.47 \pm 1.02^{\mathrm{b}}$ \\
$\mathbf{1 . 5 6}$ & $14.83 \pm 0.90^{\mathrm{a}}$ & $47.67 \pm 0.15^{\mathrm{b}}$ & $14.77 \pm 0.36^{\mathrm{b}}$ \\
$\mathbf{0 . 0 0}$ & $\mathbf{1 7 . 8 7} \pm \mathbf{0 . 3 5}$ & $\mathbf{4 8 . 8 7} \pm \mathbf{0 . 4 1}^{\mathrm{c}}$ & $\mathbf{1 3 . 7 0 \pm 0 . 4 0 ^ { \mathrm { ab } }}$ \\
\hline
\end{tabular}

Mean of 3 replicates $\pm S D$; Values with the same superscript along the same column are not significantly different $(p>0.05)$.CAT $=$ Catalase, GSH= Reduced glutathione, SOD= Superoxide dismutase

Physicochemical Characteristics:Determination of physicochemical characteristics is an important tool in maintaining quality and healthy aquatic ecosystem. In the research, Temperature and $\mathrm{pH}$ means were reported to be $29.92 \pm 1.93^{\circ} \mathrm{C}$ and $8.14 \pm 0.85$ (Table 1). This is in line with Ezike (2012) that reported Temperature and $\mathrm{pH}$ to be within permissible limit discharged from major tanneries of Kano. The observed low average mean DO of $1.60 \pm 0.38 \mathrm{mg} / \mathrm{l}$ was a common characteristic of textile and tanneries stressing aquatic life. The researcher considered depletion of Oxygen as among the factors for high mortality, oxidative stress, histopathological and haematological effects subsequently observed. It also explains why the effluent possess a strong odour as suggested by Olorunfemi et al. (2014). Increase salinity is an evident of high TDS (Bernand and Ogunlaye, 2015) and it discharge leads to alterations in osmotic conditions (Wosnie and Wondie, 2014) stressing life of some aquatic species. Nitrate has mean value of $1.19 \pm 0.05 \mathrm{mg} / \mathrm{l}$ lower than standard limits. In high concentrations, nitrate may produce asphyxiation or in infant a condition as methemoglobinemia or cancer (Ho et al., 2012). The mean level of phosphate was recorded as $16.48 \pm 0.85 \mathrm{mg} / \mathrm{l}$ exceeding limit set by NESREA (2009). Jahan et al. (2014) reported 
similar mean value of $17.1 \mathrm{mg} / \mathrm{l}$. The present result gives concern for eutrophication in that, according to some research high phosphate may inhabits the growth of algae.

Haematological Indices: A change in water quality is one of the major factors responsible for individual variations in fish haematology (Adeyemo, 2005). The reduction with slight fluctuation in packed cell volume (PCV), haemoglobin (Hb), red blood cells (RBC), mean corpuscular haemoglobin concentration (MCHC) and mean corpuscular haemoglobin $(\mathrm{MCH})$ with increase in white blood cells (WBC) and mean corpuscular volume (MCV) observed from the Table 2 is in agreement with the study of Sreelekshmy and Miranda (2016) with Arius nenga exposed to industrial effluent. And to support the present findings is the work of Parveen et al. (2013) that reported similar result with tannery effluent on Channa punctatus. The observed increase trend in $\mathrm{MCV}$ and decrease of $\mathrm{MCH}$ and $\mathrm{MCHC}$ is in good concurrence with Praveena et al. (2013) that attributed the change observed in $L$. rohita exposed to tannery effluent to defence mechanism against the toxic effect of heavy metals leading to decrease RBC's, Hb and PCV. According to the reports of Adeyemo (2005) decrease in MCV with low $\mathrm{HB}$ indicated shrinkage of RBC due to destructive action of pollutants on erythrocytes. WBC was observed to fluctuate, it means the increase in WBC counts maybe attributed to attempt of the fish to fight against antigens (Adewoye, 2010) whereas increase-decrease WBC might be indication of stress (Ajani and Awogbade, 2012). Furthermore, low WBC indicated breakdown of vital metabolic activities as a result of possible blockage in the metabolic pathway (Dahunsi and Oranusi, 2013). The observed low oxygen and varying concentrations of tannery effluent in this study may have interfered and generated the changes in blood of experimented fish.

Oxidative Stress Enzymes:It is well known that heavy metals induce the formation of free radicals within an organism leading to oxidative stress, if prolonged may result in oxidative damage (Farombi et al., 2007; Albalawi et al., 2013). In table 3, there is variation in recorded values of CAT, GSH and SOD. Studies reveal SOD and CAT to have a cooperative mechanism (Piexoto et al., 2013). Adeogun et al. (2012) observed increase in SOD and CAT activity due to presence of environmental pollutants as defence mechanism against oxidative stress. Moreover, increased in GSH levels in the liver were reported as an evidence of adaptive and protective role against oxidative stress induced by pollutants. However, this was not the case in the present study which could be attributed to elevated oxidative stress coupled with prolong exposure duration to the effluent. The outcome of CAT activity may be as a result of weakness and malfunctioning of the liver due to oxidative stress activity. On the other hand, inhibition of SOD could lead to increased oxidative stress damaging activities of the superoxide radicals reducing the activity of the enzyme CAT (Eleyele et al., 2017). The order of enzymes in the study is SOD $>$ CAT > GSH. Aich et al. (2011 and 2015) showed capability of tannery effluent to alter stress enzymes in fish organs as adaptation mechanism. All things considered, observed alterations might be due to influx of pollutants, high production of peroxide radicals or associated to duration of the fish exposed to effluent. In addition, the elevated trend and depression were evident of low DO level. It also demonstrated defensive mechanism to overcome stressful conditions generated by pollutants for metabolic impairment in the aquatic organisms.

Conclusion:The physicochemical parameters: temperature, $\mathrm{pH}, \mathrm{DO}, \mathrm{BOD}$, conductivity, salinity and nitrate conform to safety limits except phosphate which exceeds NESREA permissible limit. Haematological indices: the PCV, Hb, MCHC and $\mathrm{MCH}$ values were attributed to anaemia from low oxygen. WBC and MCV fluctuation are an indication of stress in the fish to fight against antigens. Whereas, the fluctuating trend in GSH, SOD and CAT observed in the fishes could be attributed to pollutants in the effluent such that oxidative stress enzymes can be a sensitive indicator (biomarker) of aquatic pollution. Therefore, this study further accentuates toxicity potency of tannery effluent on Clarias gariepinus. And beg for more enrich toxicity assessment, covering wider range of organisms entailing: reproductive aspectand enhanced methodological procedures.

\section{REFERENCES}

Abalaka, SE (2015). Heavy Metals Bioaccumulation and Histopathological Changes in Auchenoglanis occidentalis Fish from Tiga Dam, Nigeria. J. Environ. Health Sci. Engin., 13:67-74.

Adeogun, AO and Chukwuka, AV (2012). Toxicity of Industrial Wastewater Acting Singly or in JointRatios on Clarias gariepinus. Ame. J. Environ. Sci., 8(4):366-375.

Adeogun, AO; Ogidan, IM; Ibor, OR and Chukwuka, A V (2012). Long-Term Exposure to Industrial Effluent Induces Oxidative Stress and Affects Growth in Clarias gariepinus. Res. J. Environ. Earth Sci.,4(7):738-746. 
Adeyemo, OK (2005). Haematological and Histopathological Effects of Cassava Mill Effluent in Clarias gariepinus. Afri. J. Biomed. Rese., 8:179-183.

Aebi, H (1974). Catalase estimation. In: Bergmeyer HV (Ed.). Methods of Enzymatic Analysis. Verlag Chemical New York, 673-84pp.

Aich, A; Chattopadhyay, B; Datta, S and Mukhopadhyay, SK (2011). Impact of Composite Tannery Effluent on the Amino-transferase Activities in a Fish Biosystem, using Guppy Fish (Poecilia reticulata) as an Experimental Model. $J$. Toxico. Environ. Chem., 93(1):85-91.

Aich, A; Goswami, AR; Roy, U and Mukhopadhyay, SK (2015). Ecotoxicological Assessment of Tannery Effluent Using Guppy Fish (Poecilia reticulata) as an Experimental Model: A Biomarker Study. J. Toxico. Environ. Health, 78(4):278-286.

Ajani, F and Awogbade, AA (2012). Hematological Changes of the African Catfish Clarias gariepinus (Burchell, 1822) Juveniles Induced by Diuron. Brit. Biotechno. J., 2(4):247-256.

Akan, JC; Moses, EA; Ogugbuaja, VO and Abah, J (2007). Assessment of Tannery Industrial Effluent from Kano Metropolis, Nigeria. Asian Net. Sci. Inf., J. Appl. Sci.,7(19):2788-2793.

Akan, JC; Ogugbuaja, VO; Abdulrahman, FI and Ayodele, JT (2009). Pollutant Levels in Effluent Samples from Tanneries and Textiles of Kano Industrial Areas, Nigeria. Glo. J. Pur. Appl. Sci., 15(3):343-352.

Al-Balawi, HFA; Al-Akel, AS; Al-Misned, F; Suliman, EM; Al-Ghanim, K A; Mahboob, S and Ahmad, Z (2013). Effects of Sub-lethal Exposure of Lead Acetate on Histopathology of Gills, Liver, Kidney and Muscle and its Accumulation in these Organs of Clarias gariepinus. Braz. Arch. Biol. Technol., 56(2):293-302.

American Public Health Association, (APHA). (2005). Standard Methods for the Examination of Water and Wastewater. 21st ed. American Public Health Association, Washington DC, p.120.

American Society for Testing of Materials, (ASTM). (1990). Guide for Conducting Acute Toxicity Test with Fishes, Macro Invertebrates and Amphibians p.729-790.
Bernard, E and Ogunleye, A (2015). Evaluation of Tannery Effluent Content in Kano Metropolis, Kano State Nigeria. Int. J. Phy. Sci., 10(9):306310 .

Chowdhury, M; Mostafa, MG; Biswas, TK; Mandal, A and Saha, AK (2015). Characterization of the Effluents from Leather Processing Industries. Environ. Process.2(5):173.

Dacie, JV and Lewis SM (1984). Practical Hematology. 6th ed. New York, London: Churchill.

Dahunsi, OS and Oranusi, US (2013). Haematological Response of Clarias gariepinus to Rubber Processing Effluent. Ann. Rev. Res. Bio., 3(4):624635.

Eleyele, OA; Aladesanmi, OT; Komolafe, AO and Okonji, RE (2017). Toxicity of Multivitamins Production Effluent: A study of Oxidative Stress in Clarias gariepinus (burchell, 1822). Int. Res. J. Pub. Environ. Health, 4(6):096-111.

Ellman, GL (1959). Tissue Sulfhydryl groups. Arch. Biochem. Biophy.,82:70-77.

Ezike, NN; Udiba, UU; Ogabiela, EE; Akpan, NS; Odey, MO; Inuwa, B; Sule, AM and Gauje, B (2012). Assessment of the Performance of Primary Effluent Treatment Plant of Major Tanneries in Kano, Nigeria. Tre. Adv. Sci. Engin., 5(1):38-45.

Farombi, EO; Adelowo, OA and Ajimoko, YR (2007). Biomarkers of Oxidative Stress and Heavy Metal Levels as Indicators of Environmental Pollution in African Cat Fish (Clarias gariepinus) from Nigeria Ogun River. Int. J. Environ. Res. Public Health, 4(2):158-165.

Fridovich, I (1989). Superoxide dismutases. An Adaptation to a Paramagnetic Gas. J. Bio Chem, 264:7761-7764.

Ho, YC; Show, KY; Guo, XX; Norli, I; Alkarkhi Abbas, FM and Morad, N (2012). Industrial Discharge and their Effect to the Environment, Industrial Waste, Prof. Kuan-Yeow Show (Ed.), ISBN: 978-953-51-0253-3, InTech.

Jahan, MAA; Akhtar, N; Khan, NMS; Roy, CK; Islam, $\mathrm{R}$ and Nurunnabi (2014). Characterization of Tannery Wastewater and its Treatment by Aquatic 
Macrophytes and Algae. Bang. J. Sci. Ind. Res., 49(4):233-242.

Koçbaş, F and Oral, R (2015). Daphnia magna as a Test Species for Toxicity Evaluation of Municipal Wastewater Treatment Plant Effluents on Freshwater Cladoceran in Turkey. Turk. J. Fis. Aqu. Sci., 15:619-624.

Likita, MB; Nura, GK; Nuhu, CD and Isah, SDK (2016). Physico-Chemical Characterization of Industrial Effluents in Minna Niger State, Nigeria. Int. J. Mod. Anal. Sepa. Sci., 5(1):12-19.

Liney, KE; Hagger, JA; Tyler, CR; Depledge, MH; Galloway, TS and Jobling S (2005). Health Effects in Fish of Long-Term Exposure to Effluents from Wastewater Treatment Works. Environ. Health persp.,114(1):81-89.

National Environmental Standards and Regulation Enforcement Agency, (NESREA). (2009). Federal Republic of Nigeria Official Gazette, National Environmental (Sanitation and Waste Control). Federal Government of Nigeria Printer, Abuja, Nigeria, FGP 112/102009/L000 (OL54), 60(96):1057-1102.

Obasi, AI; Amaeze, NH and Osoko, DD (2014). Microbiological and Toxicological Assessment of Pharmaceutical Wastewater from the Lagos Megacity, Nigeria. Chin. J. Biol., p.9.

Ogundiran, MA; Fawole, OO; Adewoye, SO and Ayandiran, TA (2010). Toxicological Impact of Detergent Effluent on Juvenile of African Catfish (Clarias gariepinus). Agriculture and Biology J. North Ame.,ISSN Print: 2151-7517, ISSN Online: 2151-7525 (Buchell 1822).

Olorunfemi, DI; Olomukoro, JO and Anani, OA (2014). Acute Toxicity of Produced Water on Clarias gariepinus Juveniles. StudiaUniversitatis “VasileGoldiş", SeriaŞtiinţeleVieţii, 24:299-303.

Onyidoh, HE (2017). Assessment of Heavy Metals in Wild and Farmed African Catfish Clarias gariepinus (burchell, 1822) in Selected Rivers and Fish Farms in Kaduna State, Nigeria (Unpublished Master's dissertation). Ahmadu Bello University, Zaria, Nigeria.

Parveen, S; Singh, D; Bharose, R; Rout, S; Khan, MA and Ansari, EF (2017). Tannery Effluent Effect on the Haematological Parameters of Freshwater Fish, Channapunctatus. J. Appl. Nat. Sci., 9(1):201-205.
Peixoto, FP; Carrola, J; Coimbra, AM; Fernandes, C; Teixeira, P; Coelho, L; Conceição, I; Oliveira, MM and Fontaínhas-Fernandes, A (2013). Oxidative Stress Responses and Histological Hepatic Alterations in Barbel, Barbus bocagei, from Vizela River, Portugal. Rev. Int. Contam. Ambie., 29(1):29-38.

Praveena, M; Sandeep, V; Kavitha, N and Jayantha, RK (2013). Impact of Tannery Effluent, Chromium on Hematological Parameters in a Fresh Water Fish, Labeo rohita (Hamilton). Res. J. Ani., Vet. Fis. Sci., 1(6): 1-5.

Rajagopalan, R; Periyasamy, L and Baskaran, M (2010). Effects of Phyllanthus niruri on Alcohol and Polyunsaturated Fatty Acid Induced Oxidative Stress in Liver. Int. J. Pharma. Sci., 2:58-62.

Souza, JM; Guimarães, ATB; Silva, WAM; Pereira, CCO; Menezes, IPP and Malafaia, G (2016). Tannery Effluent Effects on Vertebrates: Lessons from Experimental Animals. Int. J. Cur. Res., 8(10):39902-39914.

Sreelekshmy, SG and Miranda MTP (2016). Impact of Industrial Effluent on the Haematological Profile in Marine Catfish, Arius nenga. Int. J. Res. Fis. Аqua., 6(1):4-7.

Tadesse, GL and Guya, TK (2017). Impacts of Tannery Effluent on Environments and Human Health. J. Environ. Earth Sci., 7(3):88-97.

Tijjani, GF and Ajani, EK (2017). Haematological Responses of C. gariepinus (Burchell, 1822) Broodstock Fed Varying Palm Oil Inclusion Levels. Nig. J. Fis. Aqua., 5(1):37-43.

Umar, M; Ibrahim, MA; Mustapha, MB; Mohammed, IB; Tashi, UT; Obafemi, A and Ahmad, GI (2017). Physicochemical Analysis and Microbiological Assessment of Tannery Effluent Discharged from Tanneries around Nigeria's Kano Industrial Estates. J. Adv. Micro., 2(1):1-12.

USEPA. (2002). Methods for Measuring the Acute Toxicity of Effluents and Receiving Waters to Freshwater and Marine Organism, Fifth edition, EPA-821-R-02- 012, Office of Water (4303T), Washington, DC.

Wakawa, RJ; Uzairu, A; Kagbu, JA and Balarabe, ML (2008) Impact assessment of effluent discharge on physicochemical parameters and some heavy metal 
concentrations in surface water of River Challawa Kano, Nigeria. Afr. J. Pur. Appl. Chem., 2(10):100106.

World Health Organization, (WHO). (2012). Potential Pollutants, their Sources and their Impacts. Guideline for Drinking Water quality (electronicResource). Retrieved from http://www.whglibdoc.who.int/publications/2006/ 9241546964.eng.pdf.

Wosnie, A and Wondie, A (2014). Bahir Dar Tannery Effluent Characterization and its Impact on the Head of Blue Nile River. Afr. J. Environ. Sci. Tech., 8(6):312-318.

Xiao, N; Qin, L; Zhang, X; Li, Y and Zhang, F (2016). Industrial Wastewater Biological Toxicity Research Status. International Conference on Energy and Environmental Protection (ICEEP), 521-526.
Zungum, IU; Imam, TS; Ahmad, AG; Abubakar, T; Benjamin, B; Daya, MG (2019). Impact of Typha Grass on Biodiversity Loss of Hadejia-Nguru Wetland Located between Jigawa and Yobe States of Nigeria: A Review. J. Appl. Sci. Environ. Manage. 23(10):1847-1853.

Zungum, IU; Imam, TS; Benjamin, B; Moisule, A; Daya, MG; Abubakar, T; Bala, ZM; Peter, DD (2020). In Vitro Assay of Bacterial Load on Some Ruminant Hide and Skin from North-Western Nigeria. J. Appl. Sci. Environ. Manage. 24(8): 1425-1432. 